\title{
Mental Readiness and Challenges faced by Health care Front liners during COVID-19 Pandemic in Malaysia
}

\author{
Siti Hajar Johari ${ }^{1}$, Abu Yazid Abu Bakar ${ }^{2 *}$, Salleh Amat ${ }^{3}$, Kadek Suranata $^{4}$ \\ ${ }^{1,2,3}$ Fakulti Pendidikan, Universitas Kebangsaan Malaysia, Malaysia \\ ${ }^{4}$ Departement Guidance and Counseling, Universitas Pendidikan Ganesha, Singaraja, Indonesia \\ *Corresponding author, e-mail: yazid3338@ukm.edu.my
}

Received May 5, 2021; Revised May, 25, 2021; Accepted May 28, 2021; Published Online May 31, 2021

\section{Conflict of Interest} Disclosures:

The authors declare that they have no significant competing financial, professional or personal interests that might have influenced the performance or presentation of the work described in this manuscript.

\begin{abstract}
The readiness and mental challenges of health care front-liners are one of the big issues that need to be addressed by the Ministry of Health Malaysia (MOH) and also the Malaysian Board of Counselors (MBC). This is to ensure that all threats to health care front-liners can be overcome in order to streamline the duties of fighting the COVID-19 pandemic in Malaysia. Therefore, this study aims to understand the readiness and mental challenges of health front workers (Font liners) in facing the COVID-19 pandemic. This study uses a qualitative design with a case study approach. The study participants consisted of two medical officers and two nurses from the states of Johor and Sabah who had more than six months of experience in handling COVID-19 cases. Study data were obtained through semistructured interview techniques. The findings state that there are two subtheme codes from the mental readiness of health care front liners and four subtrahend codes from the mental challenges of health care front liners in facing the COVID-19 pandemic. Information from this study can be used by the MOH and MBC in dealing with the possible mental health issues of the health care front liner, post-COVID-19 in Malaysia.
\end{abstract}

Keywords: COVID-19, health care front liners, mental, Malaysia

How to Cite: Johari, S.J.,Abu Bakar, A.Y., Amat, S. \& Suranata, K.(2021). Mental Readiness and Challenges faced by health care front linersners during COVID-19 Pandemic in Malaysia, BISMA the Journal of Counseling, 5 (1): pp. 28-35, DOI: http://dx.doi.org/10.23887/bisma.v4i1 


\section{Introduction}

In December 2019, a cluster of pneumonia was s detected in Wuhan, China. China has officially confirmed the outbreak to the World Health Organization (WHO) on December 31, 2019 and the daily market in Hunan was completely closed on January 1, 2020. On January 7, 2020, Chinese scientists have identified an infectious agent, a new virus. A new Corona virus which was announced as 2019-Novel Corona virus (2019-NCOV) on 12 January 2020 by WHO (Nyahsanu et al, 2020). According to Faiz and Haidar (2020), like other respiratory diseases, COVID-19 infection can cause an individual experience symptom either mild such as colds, sore throat, cough and fever or more severe such as pneumonia, difficulty breathing and can eventually lead to death. According to the World Health Organization (WHO), the incubation period of COVID19 virus is between 2 to 14 days.

COVID-19 was first reported in Malaysia on 2 January 2020. This first wave was on 17 February 2020 involving only 22 cases but until December 2020, the number of pandemic cases increased daily to a total of more than 120,818 cases throughout Malaysia. Until recently, Malaysia is among the highest Asian countries in cases of Coronavirus infection. The deaths caused by this Coronavirus are more than 501 deaths as of December 2020. (KKM, 2020; Rahim \& Atehfeh, 2020). This COVID-19 pandemic also caused panic and confusion in the fight against infection. This confusion leads to controversial decisions about who should be treated or tested with a lack of resources. Anxiety and depression towards society in the country widely across at -risk groups under normal circumstances (Sidi, 2020).

As the Movement Control Order (PKP) was launched to cut off the Covid 19 spreading, all front lines in the public sector such as doctors, nurses, police, soldiers and even firefighters were mobilized to assist the government in curbing the COVID-19 infection from spreading. The workload of frontline workers is increasing to solve a case of COVID-19 in general to some extent is very disruptive to the mental and health of frontline workers. Labrague et.al (2020) stated that frontline workers in the field of health is seen to have a very significant impact in terms of workload such as nurses and doctors in health clinics and hospitals. Health frontline workers are members of the healthcare industry appointed by the Ministry of Health Malaysia $(\mathrm{MOH})$ to help streamline all areas of work related to public health management and services throughout COVID-19 pandemic (KKM, 2020). Their main tasks is to conduct detection tests and treatment to the public in hospitals, quarantine centers and health clinics to prevent the spread of COVID19.

Many countries have taken stricter precautionary measures by declaring a state of emergency, curfew and movement control orders. The limitations resulting from these restrictions have certainly created an atmosphere conducive to stress. All healthcare professionals around the world are faced with an unprecedented situation of making difficult decisions and working under extreme pressure because many health systems are not as usual due to COVID-19, such as the way patients are handled, and also various new methods exist in health that needs to be mastered by all frontal health workers in general (Eikhwan Ali \& Mahirah, 2020).

The World Health Organization (WHO) made the statement that Pandemic COVID 19 is a new disease in which people without strong immunity or immune system are easily infected and easily spread and it is unexpected (WHO, 2020). The effects of this COVID-19 transmission lead to mental health challenges to all frontline health workers in general. These include fear, sadness, anxiety, depression, etc. (Ali el Attar, 2020). Therefore, this study focuses on the preparation and mental challenges faced by health frontline workers in facing the COVID-19 pandemic in Malaysia. The objectives of this study are to (1) identify the duties of frontline health workers in dealing with COVID-19, (2) exploring the mental readiness of frontline health workers to face COVID-19, and (3) exploring the mental challenges of frontline health workers in dealing with COVID-19.

\section{Method}

This study uses a qualitative approach. Data collection in qualitative research has been divided into four basic types such as qualitative observation, qualitative interviews, qualitative documents and qualitative audio and visual materials (Cresswell, 2017). This study involved a case study on the mental health readiness and challenges of health care front linersners in Malaysia.The case study approach is an appropriate design for this study because the data collected are narrative data resulting from semi structured interviews (Ishak et.al, 2013). 
According to Shutterworth (2020) a case study is an in -depth study of a specific situation rather than a comprehensive statistical survey. This is a method used to bridge a very broad field of research into a topic that is easy to study and analyze the challenges and mental preparation of health care front linersners in facing the COVID-19 Pandemic. This field of study is the result of semi-structured interviews of health workers in Johor and Sabah, Malaysia.

\section{Participants}

This study involving health care front linersners who are selected randomly in Johor and Sabah, Malaysia which has the highest number of COVID-19 cases in Malaysia. The selection criteria of the participants is based on the experience of the participants working in the area with the highest COVID-19 cases in Malaysia, and also their experience in dealing with COVID-19 cases for more than sixth month. Semi-structured interview was used as a method in collecting data from the participants and was conducted in seven participants with various health workers backgrounds.

All participants have given their constent to answer the online interview. The online method used to maintain social distance for the participants and researcher. Data were taken by audio that recoreded by the researcher. Seven participants were from doctor $(n=2)$ and nurses $(n=5)$. Table 1 shows the population of study participants to provide rich and accurate data to the researcher (Cresswell, 2017). In this study, the researcher did not set the age limit of study participants to answer the research questions. The purpose of this study is to understand and explore the mental health challenges of health care front linersners while handling COVID-19 cases in hospitals.

Table 01 (Participants Background)

\begin{tabular}{ccccc}
\hline \multirow{2}{*}{ Occupation } & \multicolumn{2}{c}{ Experience as front liners during COVID-19 } & Total \\
\cline { 2 - 4 } Doctor & 6 Month & 8 Month & 11 Month & 2 \\
Nurse & - & - & 2 & 5 \\
& 2 & 2 & 1 & 7 \\
\hline & \multicolumn{2}{c}{ Total } & \multicolumn{2}{c}{ Participants Background (Johari, Bakar \& Salleh, 2021) }
\end{tabular}

\section{Data Analysis}

This study uses two online interview methods namely asynchronous and synchronous interviews (Stewart \& Williams, 2005; Janghorban et al., 2014). According to Nursyairah, Izal \& Chea (2020) the use of this method is due to the geographical factors of a wide sample. The synchronous method refers to interviews conducted at the same time as the use of ZOOM. The use of video chat technology (, for example, can clearly tell the facial movements and body movements of the sample when answering a question. Asynchronous method is an interview method that is conducted non -simultaneously but still online. This method of conducting online interviews was adopted in line with the COVID-19 social distance guidelines preventing transmission from one person to another (Singh \& Adhikari, 2020). All research questions were constructed by the researcher and have received feedback from other researchers. A total of 2 experts in this study have provided an evaluation of the interview research questions of the study participants.

The interview session was conducted in 40 minutes. The interview was stopped after reaching the saturation point, that is, when there was no more new data generated from the interview. Interviews were held between October 2020 and November 2020. All interviews of the study participants were audio recorded and verbatim transcribed before being analyzed. The data were analyzed thematically and the emerging themes were supported by excerpts from the interviews conducted on the study participants. According to Heriyanto (2018), in thematic analysis researchers need to take the time to know more closely the data they obtain before doing the next stage.

\section{Research Ethics}

All participants were given a notification form about the study before participating in the research study. They also had the opportunity to ask questions. In addition, participants signed a consent form, which also gave them the right to withdraw from the study at any time without giving reasons. Because the study subjects were sensitive, the researcher also provided information on counseling and support services to the participants.

\section{Results and Discussion}

\section{Results}


The results of interview with participants show on table below. Table 2 shows two subthemes on the mental readiness of health care front liners nears in facing the COVID-19 pandemic. Table 3 shows that there are 4 subthemes of mental challenges faced by health care front liners during COVID-19 pandemic..

Table 2. The Mental Readiness of health care front liners nears in facing the COVID-19 Pandemic

\begin{tabular}{lcc}
\hline \multicolumn{1}{c}{ Subthemes collected from Data Acquisition } & $\begin{array}{c}\text { Participants } \\
\text { Doctor }\end{array}$ & $\begin{array}{c}\text { Participants } \\
\text { Nurse }\end{array}$ \\
\hline Understand the workload and responsibilities as & PK 2, PK 4 & PK 1, PK 3, PK \\
a COVID-19 officer & 5, PK 6, PK 7 \\
Comply with the Standard Operating Procedures & PK 2, PK 4 & PK 1, PK 3, PK \\
(SOP) of the Ministry of Health Malaysia & & 5, PK 6, PK 7 \\
(MOH) & & PK 1, PK 3, PK \\
Mental and physical preparation & & 5, PK 6, PK 7 \\
\hline
\end{tabular}

\section{Subtheme 1: Understanding the workload and responsibilities as a COVID-19 officer}

health care front liners nears stated a heavy workload and responsibility throughout their role as front liners officers for the COVID-19 Pandemic. Participants stated the areas of work that they have to face in the clinic and also in the hospital as stated by PK 1, PK 3 and PK 4:

"I was assigned as a swab test taker" -PK 1

"I was assigned to take care of the screening ward (PUI) which is a ward for COVID-19 patients"-PK 3

"Oh..I manage all parts such as managing PUI samplers, care and reassessment of COVID-19 patients, I am also a report maker for all reports of all forms of COVID-19 reports in my area., I am also directly involved in human resource management and also work as an officer of the patient and public complaints section related to the COVID19 Pandemic "'-PK 4

\section{Subtheme 2: Comply with Standard Operating Procedures (SOP) Ministry of Health Malaysia (MOH)}

The Ministry of Health Malaysia (MOH) has outlined various Guidelines for Safety Procedures (SOP) for all medical officers and medical assistants to prevent infection of the COVID-19 virus among health workers. This is stated by PK 1 and PK 2:

"SOP is followed such as wearing a face mask at all times, wearing PPE and always maintain hand hygiene by using alcohol, prayer and always trust" - PK 1

"I have to follow the SOPs directed by the Ministry of Health Malaysia (MOH) such as the use of PPE that heats up, wearing a 3 -layer face mask that is suffocating and also always ensure hands are washed using alcohol and soap provided at work." - PK 2

\section{Subtheme 3: Physical and mental preparation}

According to participants experience, they need to prepare themselves physically and mentally as they understand their increasing field of work as well as their various job changes. Participants also understood the risks they would have when faced with the COVID-19 Virus pandemic as described below:

"I need to prepare anytime, anywhere for all possibilities, physically exhausted, mental and physical stress, non-stop work, risk to family, colleagues and friends"-PK 4

"In terms of physical and mental preparation, I need to think positive always. "-PK 5

"I have to be physically prepared because I know I have to work overtime and have no time to rest" -PK 3

"I have to face long working hours and less rest time" -PK 6

"I must always be prepared for any eventuality" -PK 4 
Table 3. (Mental challenges faced by health care front linishers during COVID-19 pandemic)

\begin{tabular}{lcc}
\hline \multicolumn{1}{c}{ Subthemes collected from Data Acquisition } & $\begin{array}{c}\text { Participants } \\
\text { Doctor }\end{array}$ & $\begin{array}{c}\text { Participants } \\
\text { Nurse }\end{array}$ \\
\hline Workload/task stress & PK 2, PK 4 & PK 1, PK 3, PK \\
& & 5, PK 6, PK 7 \\
Fear/anxiety of infection towards self and family & PK 2 & PK 3, PK 7 \\
Lack of commitment to self and family & PK 4 & PK 1, PK 5 \\
Fatigue & PK 2, PK 4 & PK 1, PK 3, PK \\
& & 5, PK 6, PK 7 \\
\hline \multicolumn{2}{c}{ (Johari, Bakar \& Salleh, 2021) }
\end{tabular}

\section{Subtheme 1: Workload/task stress}

The main challenge in the job as COVID-19 health care front linishers is the stress of their workload. This is because the increase in patients and close contact to the virus has made the mental health of front liners a little disturbed. Interviews of participants on this matter can be seen through this verbatim:

"I'm tired, stressed, work overload, my emotions are not good and also my hormones are unstable" -PK 4

"My stress is more on long working hours and I do not rest enough" - PK 2

"I feel pressure because the public/society stigma on front liners when front liners are in public" -PK $\mathbf{5}$

"Challenges in terms of physical and mental such as stress from the increase in cases every day, lack of PPE from the hospital and so on" -PK 3

"Stress when I'm in a public place. This is because the public is afraid to approach me when they know I am one of the COVID-19 officers "-PK2

\section{Subtheme 2: Fear/anxiety of infection towards self and family}

The challenge for health care front linishers is related to their fears and anxieties about whether the virus is infected or will cause those closest to them to be infected by the virus. Study participants voiced their concerns, and this can be seen from their interviews:

"Always feel insecure when with family, especially those with small children or the elderly" -PK 5

"My family is worried that I will be infected, in fact I am also worried that my family will get an infection from me" -PK 4

"I'm worried about my family because I'm afraid of bringing the virus into the house" -PK $\mathbf{5}$

\section{Subtheme 3: Lack of commitment to self and family}

The next challenge was that Study Participants had less commitment with their families as well as with themselves. This is because they have to work overtime and also help patients who are infected at a fast rate. This can be seen from the verbatim below:

"I am stressed because my children and husband are not taken care of, my parents help manage the children because I spend a lot of time in the clinic to manage COVID-19 patients" -PK 2

\section{Subtheme 4: Fatigue}

Study participants stated that they are tired in carrying out their duties as heatlhcare front liners Their fatigue is seen when the non-stop working hours when the increase in patients in the hospital is caused by this COVID-19.

"I'm tired" -PK 4

"I'm tired and stressed" -PK 2

"I'm tired when I meet people who are a lot of fuss when doing swab tests" - PK 5 


\section{Discussion}

The readiness of health front liners is very important in carrying out responsibilities to the community in curbing the COVID-19 virus chain from spreading in Malaysian society in general. From the findings of the study, all research questions were answered when the data from the interviews in the process and obtained some sub themes of the study questions. Preparation of health front liners are well prepared and understand the duties and responsibilities as case managers of Covid-19 (MOH, 2019). The tasks entrusted to them such as screening and taking swab tests on people infected with the virus COVID-19 (PUI) and also screen close contact to people suspected of having COVID-19 infection, patient management to quarantine centers designated by the Ministry of Health Malaysia $(\mathrm{KKH})$ and also various health reports related to COVID-19 patients. According to Daud (2020), front liners employees must develop and configure new existing capabilities from time to time according to the latest trends. The dynamic abilities that front liners workers need to have in order to be the potential for them to feel the opportunities and threats to make the right decisions and be able to combat the spread of this epidemic successfully.

All front liners must understand and comply with the Standard Operating Procedures (SOP) set by the Ministry of Health Malaysia (MOH) such as wearing standard safety clothing (PPE) at all times and wearing 3 layers of face at all times on duty and hand hygiene. In addition, compliance with COVID-19 patient and non-patient isolation standards is also under the authority of health frontliners. All health front liners need to be physically and mentally prepared because of their high risk to self and family. Them .All of these areas of work to some extent contribute to the mental health challenges of health frontliners.

The third question is about the challenges of COVID-19 health front liners. The main challenge of COVID-19 Front liners is the stress of a heavy workload, so they work overtime. This causes them stress and less rest. They are also stressed with various procedures that they need to follow to reduce COVID-19 infection among staff. According to Hishami et. al (2020) One of the strategies to empower health workers in combating the effects of this COVID-19 pandemic is through effective training. The modules produced are self-protective device (PPE), airway management and cardiopulmonary resuscitation for patients suspected of COVID-19. With the construction of this module, health workers are a little stressed with the rules they have to follow to prevent COVID-19 infection.

These front liners have fears and anxieties about themselves. In the study, there were 3 health front liners who were in anxiety and fear of the COVID-19 virus. They were worried if the virus was infected by them and also infects immediate family such as children and spouses. They also have less commitment to family as well as themselves. All of these health front liners worked for almost 12 hours at clinics and hospitals to facilitate the travel of COVID-19 positive cases at quarantine centers and COVID-19 health hubs. Their commitment with their families as well as themselves becomes less due to the effects of burdensome task schedulers. These front liners are tired and fatigued with the situation they are experiencing. They are less motivated, and their health is also somewhat declining. The data from this study also explains the increasing workload of health front liners as the number of cases of infection increases every day.

\section{Conclusion}

This study has implications for the field of health and also in the field of counseling in Malaysia. Ministry of Health Malaysia and the Board of Counselors Malaysia in general. This is because these two professionals play a very important role in addressing issues that arise among front liners. health in their mental health challenges. The findings of the COVID-19 workload and anxiety study in front liners indicate that it needs to be addressed immediately. In conclusion, this study shows that health front liners need to be helped psychologically. The 2019 corona virus pandemic (COVID-19) has a profound effect on all human lives Holmes et al. (2020). The COVID-19 pandemic has affected humanity globally to all people, families and communities.

\section{Acknowledgment}

Acknowledge anyone who has helped you with the study, including: Researchers who supplied materials, reagents, or computer programs; anyone who helped with the writing or English, or offered 
critical comments about the content, or anyone who provided technical help. State why people have been acknowledged and ask their permission. Acknowledge sources of funding, including any grant or reference numbers. Please avoid apologize for doing a poor job of presenting the manuscript.

\section{References}

Altahir, A., Mathur, N., Thiruchelvam, L., Mustafa Abro, G., Radzi, S., Dass, S., Gill, B. S., Zulkifli, S., \& Asirvadam, V. (2020). Modeling the Impact of Lock-down on COVID-19 Spread in Malaysia.May.https://doi.org/10.1101/2020.07.17.208371.

Asri, N. S., Wen, K. C., \& Zolkepli, I. A. (2020). Pembinaan Kepercayaan dan Persepsi Risiko dalam Pembuatan Keputusan: Kajian Kes Komuniti 'Couchsurfing' (Trust Building and Perceived Risk in Decision-Making Process: The Case Study of Couchsurfing Community). Jurnal Komunikasi: Malaysian Journal of Communication, 36(2), 235-252. https://doi.org/10.17576/jkmjc-2020-3602-14

Azizan, M., Daud, M., \& Awang, A. H. (2020).Insan bagi pekerja Barisan Hadapan COVID-19.July.

Eikhwan Ali,\& Mahirah A Rashid. (2020). Pandemik covid 19 mendepani impak psikososial.Tsis, 11, 114.

Faiz.I \& Haidar. (2020). Dalam pengurusan Pandemik COVID-19, Universiti Kebangsaan Malaysia

Holmes, E.A., O'Connor, R.C., Perry, V.H., Tracey, I., Wessely, S., Arseneault, L., Ballard, C., Christensen, H., Cohen Silver, R., Everall, I., Ford, T., John, A., Kabir, T., King, K., Madan, I., Michie, S., Przybylski, A.K., Shafran, R., Sweeney, A., Worthman, C.M., Yardley, L., Cowan, K., Cope, C., Hotopf, M., Bullmore, E. 2020. Multidisciplinary research priorities for the COVID19 pandemic: a call for action for mental health science. Lancet Psychiatry 7(6): 547-60.

Iranian, A. (2020). Letter to the Editor COVID-19 and mental health : An Iranian perspective. 54(May), 2019-2020. https://doi.org/10.1016/j.ajp.2020.102266

Ishak, N. M., Yassin, S. F. M., Hamzah, M. I. M., \& Ariffin, S. R. (2013). Kajian Kes. Penyelidikan Dalam Pendidikan, 355.

John W.Creswell \& John David Cresswell (2017).Research Design: Qualitative, Quantitative, and Mixed Methods Approaches $5^{\text {th }}$ edition,ISBN-13: 978-1506386706

Labrague, L. J., \& De los Santos, J. A. A. (2020). COVID-19 anxiety among front-line nurses: Predictive role of organisational support, personal resilience and social support. Journal of Nursing Management, 28(7), 1653-1661. https://doi.org/10.1111/jonm.13121

Meyer, S., \& Morand, M.-B. (2015). Mental health and psychosocial support in humanitarian settings. Intervention, 13(3), 235-247. https://doi.org/10.1097/WTF.0000000000000089

Mohd Saiboon, I. (2020). The Preparation, Delivery and Outcome of COVID-19 Pandemic Training Program among the Emergency health care front linersners (EHFs): The Malaysian Teaching Hospital Experience. Medicine \& Health, 15(1), 250-265. https://doi.org/10.17576/mh.2020.1501.23

Nyashanu, M., Pfende, F., \& Ekpenyong, M. (2020). Exploring the challenges faced by frontliner workers in health and social care amid the COVID-19 pandemic: experiences of frontline workers in the English Midlands region, UK. Journal of Interprofessional Care, 34(5), 1-7. https://doi.org/10.1080/13561820.2020.1792425

See, K. C., Liew, S. M., Ng, D. C. E., Chew, E. L., Khoo, E. M., Sam, C. H., Sheena, D., Zahilah Filzah, Z., Chin, S. Y., Lee, P. Y., Tan, L. P., Farah Najwa, Z., Sabrina, S., Them, W. W., Saipriya, T., Muhammad Zamakhshari, Z. A., Cheah, W. K., Peariasamy, K., Goh, P. P., \& Ibrahim, H. (2020). COVID-19: Four Paediatric Cases in Malaysia. International Journal of Infectious Diseases, 94, 125-127. https://doi.org/10.1016/j.ijid.2020.03.04

Sidi, H. (2020). The Psychological Sequelae during Mental Health and COVID-19 Pandemic: Learning from the Past for Today's Coping Styles. Medicine \& Health, 15(1),1-4. https://doi.org/10.17576/mh.2020.1501.01

Singh, R., \& Adhikari, R. (2020).Age-structured impact of social distancing on the COVID-19 epidemic in India.arXiv preprint arXiv:2003.12055.

Umaira, A., Safri, A., \& Thevadas, R. (2020). International Journal of Infectious Diseases COVID-19 outbreak in Malaysia:Actions taken by the Malaysian government. 97, 108-116. https://doi.org/10.1016/j.ijid.2020.05.093 


\section{Conflict of Interest Disclosures:}

The authors declare that they have no significant competing financial, professional or personal interests that might have influenced the performance or presentation of the work described in this manuscript.

Copyrights Holder: < Siti Hajar Johari, Abu Yazid Abu Bakar, Salleh Amat, \& Suranata, K $><2021>$

First Publication Right: BISMA The Journal of DOI: http://dx.doi.org/10.23887/bisma.v4i1

Counseling

Open Access Article | CC-BY Creative Commons Attribution 4.0 International License.

Word Count: 4212 cc) creative 